\section{Hydrochemical Characteristics and Potability Indices of Groundwater from Ogbia Local Government Area of Bayelsa State, Nigeria}

\section{Chikwe TN ${ }^{1}$ and Onojake $\mathrm{MC}^{1,2^{*}}$}

${ }^{1}$ Department of Pure and Industrial Chemistry, Petroleum and Environmental Chemistry Research Group, University of Port Harcourt, Nigeria.

${ }^{2}$ Centre for Marine Pollution Monitoring and Seafood Safety, University of Port Harcourt, Nigeria.

*Corresponding author: Onojake MC, Department of Pure and Industrial Chemistry, Petroleum and Environmental Chemistry Research Group, University of Port Harcourt, P.M.B 5323, Choba, Port Harcourt, Nigeria, Tel: +234-8035404696; E-mail: ononed@yahoo.com

Received date: June 02, 2018; Accepted date: June 11, 2018; Published date: June 15, 2018

Copyright: @ 2018 Chikwe, et al. This is an open-access article distributed under the terms of the Creative Commons Attribution License, which permits unrestricted use, distribution, and reproduction in any medium, provided the original author and source are credited.

\begin{abstract}
Groundwater samples from five locations in Ogbia Local Government Area of Bayelsa State were analyzed for the physicochemical properties and trace metals concentration using American Standard for Testing and Materials methods while the trace metals were determined using Atomic absorption spectroscopy. Results show pH ranged from 7.10 to 7.30 ; conductivity 14.00 to $20.00 \mu \mathrm{Scm}^{-1}$; alkalinity 3.00 to $4.60 \mathrm{mg} / \mathrm{L}$, total dissolved solid 6.00 to $105.00 \mathrm{mg} / \mathrm{L}$; total suspended solids 0.50 to $0.90 \mathrm{mg} / \mathrm{L}$, hardness 3.00 to $5.00 \mathrm{mg} / \mathrm{L}$; sulphates $0.02 \mathrm{mg} / \mathrm{L}$; nitrates $0.02 \mathrm{mg} / \mathrm{L}$; chloride 11.80 to $31.20 \mathrm{mg} / \mathrm{L}$. The concentrations of the trace metals were: Ca 2.00 to $3.00 \mathrm{mg} / \mathrm{L} ; \mathrm{Mg}$ 1.00 to 2.00; Fe 0.84 to $1.26 \mathrm{mg} / \mathrm{L} ; \mathrm{Zn} 0.02$ to $1.00 \mathrm{mg} / \mathrm{L} ; \mathrm{Cu} 0.06 \mathrm{mg} / \mathrm{L} ; \mathrm{Cr} 0.19 \mathrm{mg} / \mathrm{L} ; \mathrm{Ni} 0.19 \mathrm{mg} / \mathrm{L}, \mathrm{Cd} 0.02$ to 0.32 $\mathrm{mg} / \mathrm{L} ; \mathrm{Pb} 0.38 \mathrm{mg} / \mathrm{L} ; \mathrm{Na} 6.45$ to $3.74 \mathrm{mg} / \mathrm{L}$. The concentration of trace metals such as $\mathrm{Ni}, \mathrm{Cd}$, and $\mathrm{Pb}$ were above World Health Organization (2006) permissible limit for drinking water. The Computed Water Quality Index (WQI) and Metal Pollution Index (MPI) of groundwater samples from the five locations shows that they require mild treatment before they can be suitable for drinking because trace metals which are regarded as systemic toxicants are known to cause various organ damage.
\end{abstract}

Keywords: Groundwater; Trace metals; Water quality index; Metal pollution index; Toxicity

\section{Introduction}

Groundwater being the major source of borehole water is a significant resource for the agricultural, industrial sectors and serve as a major source of potable water for most developing countries. It is vulnerable to pollution by hazardous chemicals, trace metals and microbial activities due to its continuous interaction with surface water [1]. Research has shown that industrial and agricultural activities are sources of pollutants in both surface and ground water with surface water accumulating higher concentration of trace metals than groundwater. The direction of water flow determines trace metal concentration [2]. Water pollution does not only impact water quality, but adversely affect human health, economic development, and social prosperity [3]. Groundwater pollution has become a serious environmental problem in our contemporary time, because metal and chemical contamination shows high toxicity even at small concentration.

The Niger Delta area in recent years have experienced indiscriminate discharge of effluent, non-consumables, unused raw materials from pharmaceutical, cement, paint, steel, brewery and other manufacturing industries. This have led to the release of hazardous chemicals and trace metals into the urban aquifers which serves as the major source of drinking water for inhabitants in the area [4,5].

Hydrochemical assessment of water quality is important because it reveals the suitability of water for drinking, agriculture and industrial purposes. Also determination of the quality plays a major role in supporting agricultural production and human health.
Ground and surface water for drinking purposes must meet quality standard requirement.

Groundwater in a muddy aquifer, possibly the prevailing type of aquifer in the coastal areas such as the Niger Delta area is comparatively susceptible to the contamination by seawater intrusion which affect the portability. The resultant effect of chemical and biochemical interaction between groundwater and contaminants from industrial, municipal activities and with geological materials through which it flows, it contains a wide variety of dissolved inorganic chemical constituents in various concentrations. When seawater intrusion is the only cause for the salinity of groundwater in an aquifer system, the groundwater does not only exhibit high total dissolved solids (TDS) but also shows high concentrations of most major cations and anions [6]. Hydrochemical data helps in estimating the extended of mixing, the circulating pathways and residence time of groundwater. The physical, chemical and microbial characteristics of water are considered when determining the portability indices.

Water quality indices are one of the most effective means of obtaining data on the quality of any water body [7]. Water Quality Index (WQI) is one of the current methods of assessing the quality of any water body. It is a contemporary mathematical tool which can provide a distinct number for the enormous quantities of water quality data in an all-inclusive manner. Therefore, it is a modest tool of choice for assessing the quality and possible usages of a particular water body [8-10].

Heavy metal pollution index (HPI) is used to rate the collective contributions of the individual heavy metals on the general quality of water and can be used in obtaining a combined influence of all the metals on overall pollution [11]. In recent times, numerous researchers 
have been assessing water quality and its suitability for drinking purposes using water quality indices methods [12-15].

Some researchers have used metal pollution index (MPI) to classify water as very pure, pure, slightly affected, moderately affected, strongly affected, seriously affected depending on the result from empirical data $[16,17]$.

The aim of this study was to investigate the quality status of some groundwater samples from Ogbia Local Government area in Bayelsa State using the hydrochemical characteristics and some portability indices.

\section{Materials and Methods}

\section{Description of study area}

The sampling site is Ogbia Local Government Area of Bayelsa State in the Niger Delta region of Nigeria between latitudes $4^{\circ} 39^{\prime}$ and $50^{\circ}$ $2^{\prime} \mathrm{N}$ and longitudes $6^{\circ} 15^{\prime} \mathrm{E}$ and $6^{\circ} 45^{\prime} \mathrm{E}$ (Figure 1). The study area enjoys tropical climate with well-defined wet and dry seasons. It has an area of $695 \mathrm{~km}^{2}$ and a population of 179,926 . Its historic value stems from the fact that it is the area where Oloibiri is located. A reasonable land area of Bayelsa State lies under water at high tide considering the fact that the topographical map of the state indicates land surfaces between 12 and 15.5 meters above sea level [18]. The main drainage system of the state has deltaic plains that lie below 2.5 meters above sea level which implies that as much as $60 \%$ of the region is overrun by very high tide. The topography of the entire Niger Delta is made up of creeks and swamps passing through low lying plains in different dimensions however, the study area is basically drained by the Ogbia and Ekoli creeks which empty into the brass River. The clayey insertions within the Benin formation gives rise to various aquifer systems within the study area $[19,20]$. The average depths for boreholes in the study area are between 60 and 90 meters [18]. Deep boreholes in the study area obtain water from the confined aquifer from depths up to about 200 meters. There is arguably a high concentration of certain ground water parameters and gradual sliding of saltwater or brackish water into the fresh water aquifers [21]. Due to high industrial and agricultural activities, the area is exposed to both surface and groundwater pollution.

\section{Sample collection and analysis}

Groundwater samples from five different locations were collected in triplicate from Ogbia Local Government area of Bayelsa state (3 samples from each location) were obtained using 1.5 litres plastic bottles which were pre-rinsed with $\mathrm{HNO}_{3}$ and deionized water. The depth of the groundwater is between $90-180 \mathrm{~m}$. Samples were labeled A to E corresponding to the sampling locations. Samples were placed in a container with ice packs and transported to the Laboratory and preserved in the refrigerator prior to analysis. Physicochemical parameters such as $\mathrm{pH}$, conductivity, total suspended solids (TSS) were analyzed quantitatively using $\mathrm{pH}$ meter, innolab conductivity meter and pressure millipore vacuum pump assembly respectively while alkalinity and total hardness were determined with a metroohm titrator. Anions such as sulphates, nitrates and chlorides were measured using a DR 2800 spectrophotometer, whereas trace metal concentration with the use of an Atomic Absorption Spectrophotometer. Samples for each location were run in triplicates and the mean recorded and relative standard deviation for the triplicate analyses was less than $10 \%$. All parameters were determined based on American Standard for Testing and Materials (ASTM) [22].

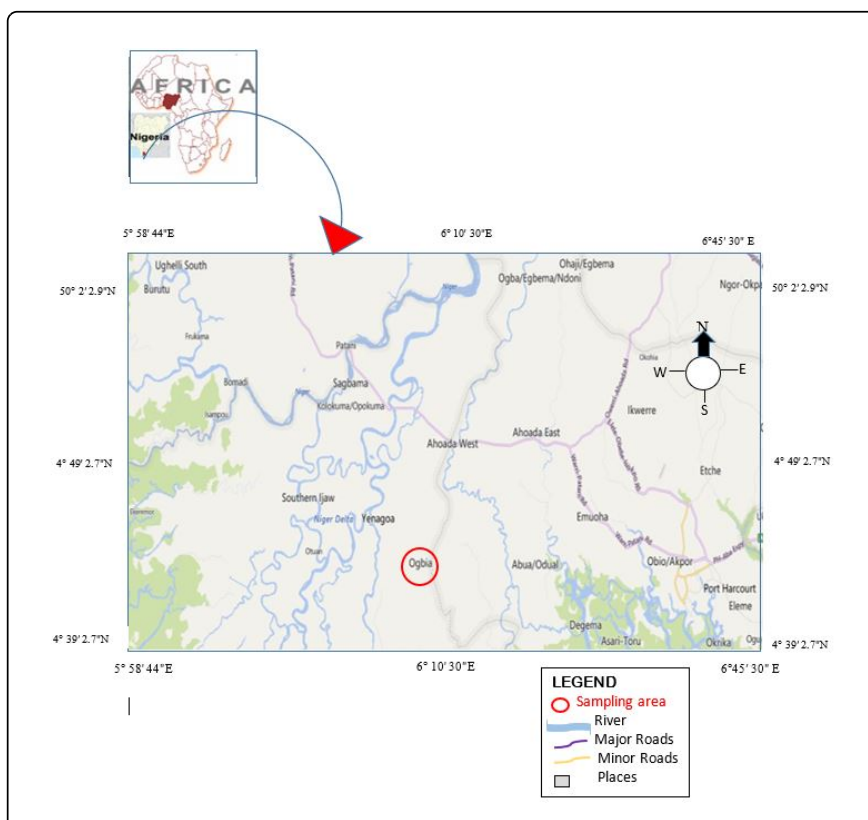

Figure 1: Map of the study area.

\section{Metal pollution index (MPI)}

One of the indices applied in determining the quality of water is the Metal pollution index (MPI), it shows the impact of each metal concentration on the overall quality of water [23]. It is usually rated between zero and one showing the relative importance individual parameters has on water quality. The higher the metal concentration compared to its maximum allowable unit the worse the water quality. MPI can be applied in determining the quality of sea, river as well as drinking water.

The total metal content at the different sites where compared using MPI according to the equation stated in Equation 3 below:

$$
M P I=\left(C f_{1} \times C f_{2} \ldots C f_{\mathrm{n}}\right)^{1 / \mathrm{n}} \text {. }
$$

Where, $\mathrm{Cfn}=$ Concentration of the metal in the sample

MPI value $>1$ is a threshold of warning.

\section{Water quality index (WQI)}

Whilst MPI indicates the influence of each metal concentration on the overall quality of water, the WQI indicates the influence of natural and man-made activities on the key parameters of ground water which happens to be the primary source of borehole water. WQI gives a holistic view of the impact of the individual (not just metallic ions) on the overall water quality [24]. The WQI is calculated by assigning a weight $\left(\mathrm{w}_{\mathrm{i}}\right)$ within the range of 1 to 5 to physiochemical parameters according to their relative importance. The maximum weight of 5 was assigned to nitrate and TDS, TSS and hardness, 4 for $\mathrm{pH}$, electrical conductivity, alkalinity and sulphate, 3 for chloride, 2 for calcium, sodium and zinc and weight 1 for the other trace metals as shown in Table 3 [25].

The relative weight is calculated with the equation below: 
Citation: Chikwe TN, Onojake MC (2018) Hydrochemical Characteristics and Potability Indices of Groundwater from Ogbia Local Government Area of Bayelsa State, Nigeria. J Environ Anal Chem 5: 244. doi:10.4172/2380-2391.1000244

Page 3 of 6

$$
W i=\frac{w i}{\sum_{i=1}^{n} w i}
$$

\section{$W_{\mathrm{i}}=$ relative weight}

$W_{\mathrm{i}}=$ weight of a parameter

\section{n=number of parameters}

The quality rating which is based on the concentration of the $\mathrm{i}^{\text {th }}$ parameter is obtained by dividing the concentration of each parameter in the water sample by the respective standard as stipulated by World Health Organization (WHO) and the result multiplied by 100 as shown in the equation below:

$$
q_{\mathrm{i}}=\left(C_{\mathrm{i}}\left(S_{\mathrm{i}}\right) \times 100 .\right.
$$

Where, $q_{\mathrm{i}}=$ quality rating

\section{$C_{\mathrm{i}}=$ Concentration of each parameter in $\mathrm{mg} / \mathrm{l}$}

\section{$S_{\mathrm{i}}=$ WHO Standard for each parameter}

To finally calculate WQI the standard is determined for each parameter using the equation below:

$$
S I_{\mathrm{i}}=W_{\mathrm{i}} \times q_{\mathrm{i}} \text {. }
$$

The sum of the Sli values gives the WQI for each sample as shown in Equation 6 below.

$\mathrm{WQI}=\Sigma \mathrm{Sl}$

WQI is an important rating that gives an incline on the impact of individual parameter on the overall quality of water.

\section{Results and Discussion}

Results of physicochemical parameters for water samples obtained from the study area are presented in Table1.

\begin{tabular}{|l|l|l|l|l|l|l|}
\hline \multicolumn{7}{|c|}{ Samples } \\
\hline Parameters & A & B & C & D & E & $\begin{array}{l}\text { WHO } \\
\text { permissible } \\
\text { limit }\end{array}$ \\
\hline pH & 7.3 & 7.2 & 7.2 & 7.3 & 7.1 & $6.5-8.5$ \\
\hline Conductivity & 14 & 224 & 19.2 & 17.1 & 20 & 1000 \\
\hline Alkalinity & 4.6 & 3 & 4 & 4.3 & 3.7 & $<5.000$ \\
\hline TDS & 6 & 105 & 9 & 8 & 9 & 500 \\
\hline TSS & 0.9 & 0.5 & 0.5 & 0.5 & 0.75 & 500 \\
\hline Hardness & 5 & 4 & 4 & 3 & 3.5 & 180 \\
\hline Sulphates & 0.02 & 0.02 & 0.02 & 0.02 & 0.02 & 250 \\
\hline Nitrates & 0.02 & 0.02 & 0.02 & 0.02 & 0.02 & 45 \\
\hline Chloride & 15.1 & 31.2 & 17.9 & 11.8 & 12.7 & 250 \\
\hline
\end{tabular}

Table 1: Mean Water Quality Variables of the Groundwater samples.

The range values of $\mathrm{pH}$, conductivity, alkalinity, TDS, TSS, hardness, sulphates, nitrates and chloride are 7.1-7.3, 14.0-224.0 mg/L, 3.0-4.6 $\mathrm{mg} / \mathrm{L}, \quad 8.0-105.0 \mathrm{mg} / \mathrm{L}, \quad 0.5-0.9 \mathrm{mg} / \mathrm{L}, \quad 3.0-5.0 \mathrm{mg} / \mathrm{L}, \quad 0.02 \mathrm{mg} / \mathrm{L}$, 11.80-31.2 respectively. Table 2 shows the mean concentration of metals and the metal pollution indices (MPI) of water samples from the study area where as Table 3 shows the mean concentration of the

\begin{tabular}{|c|c|c|c|c|c|c|c|c|c|c|c|}
\hline \multicolumn{12}{|c|}{ Metals } \\
\hline $\begin{array}{l}\text { Sampl } \\
\text { e }\end{array}$ & $\mathrm{Ca}$ & $\mathbf{M g}$ & $\mathrm{Fe}$ & $\mathrm{Zn}$ & $\mathrm{Cu}$ & $\mathrm{Cr}$ & $\mathrm{Ni}$ & Cd & $\mathrm{Pb}$ & $\mathrm{Na}$ & MPI \\
\hline A & 3 & 2 & 0.84 & 0.02 & 0.06 & 0.19 & 0.2 & 0.28 & 0.38 & 6.72 & 0.42 \\
\hline B & 2 & 2 & 1.16 & 0.02 & 0.06 & 0.19 & 0.2 & 0.23 & 0.38 & 21.5 & 0.46 \\
\hline C & 2 & 2 & 0.95 & 1 & 0.06 & 0.19 & 0.2 & 0.02 & 0.38 & 6.45 & 0.46 \\
\hline D & 2 & 1 & 1.26 & 0.02 & 0.06 & 0.19 & 0.2 & 0.32 & 0.38 & 7.45 & 0.4 \\
\hline$E$ & 2.5 & 1.5 & 0.95 & 0.02 & 0.06 & 0.19 & 0.2 & 0.02 & 0.38 & 13.7 & 0.33 \\
\hline
\end{tabular}
physiochemical parameters and metal concentration in water samples from the five sampling sites.

\begin{tabular}{|c|c|c|c|c|c|c|}
\hline Parameters & $\begin{array}{l}\text { WHO } \\
\text { limit }\end{array}$ & $\begin{array}{l}\text { Mean } \\
\text { Conc. } \\
\text { (Ci) }\end{array}$ & $\begin{array}{l}\text { Qualit } \\
\text { y } \\
\text { Rating } \\
\text { (qi) }\end{array}$ & $\begin{array}{l}\text { Weight } \\
\text { (wi) }\end{array}$ & $\begin{array}{l}\text { Relative } \\
\text { Weight } \\
\text { (Wi) }\end{array}$ & Sli \\
\hline $\mathrm{pH}$ & $6.5-8.5$ & 7.22 & 84.94 & 4 & 0.08 & 6.456 \\
\hline Conductivity & 1000 & 58.86 & 5.89 & 4 & 0.08 & 0.45 \\
\hline Alkalinity & 4.9 & 3.92 & 80 & 4 & 0.08 & 6.08 \\
\hline TDS & 500 & 27.4 & 5.48 & 5 & 0.1 & 0.52 \\
\hline TSS & 500 & 0.63 & 0.13 & 5 & 0.1 & 0.01 \\
\hline Hardness & 180 & 3.9 & 2.17 & 5 & 0.1 & 0.21 \\
\hline Sulphates & 250 & 0.02 & 0.01 & 4 & 0.08 & 0 \\
\hline Nitrates & 45 & 0.02 & 0.04 & 5 & 0.09 & 0 \\
\hline Chloride & 250 & 17.74 & 7.1 & 3 & 0.06 & 0.4 \\
\hline $\mathrm{Ca}$ & 75 & 2.3 & 3.07 & 2 & 0.04 & 0.12 \\
\hline $\mathrm{Mg}$ & 50 & 1.7 & 3.4 & 2 & 0.04 & 0.13 \\
\hline $\mathrm{Fe}$ & 50 & 1.03 & 2.06 & 1 & 0.02 & 0.04 \\
\hline $\mathrm{Zn}$ & 3 & 0.22 & 7.2 & 2 & 0.04 & 0.27 \\
\hline $\mathrm{Cu}$ & 2 & 0.06 & 3 & 1 & 0.02 & 0.06 \\
\hline $\mathrm{Cr}$ & 0.05 & 0.19 & 380 & 1 & 0.02 & 7.22 \\
\hline $\mathrm{Ni}$ & 0.02 & 0.19 & 950 & 1 & 0.02 & 18.05 \\
\hline $\mathrm{Cd}$ & 0.003 & 0.17 & 5800 & 1 & 0.02 & 110.2 \\
\hline $\mathrm{Pb}$ & 0.01 & 0.38 & 3800 & 1 & 0.02 & 72.2 \\
\hline \multirow[t]{2}{*}{$\mathrm{Na}$} & 200 & 11.17 & 5.59 & 2 & 0.04 & 0.21 \\
\hline & & & & $\sum_{0} w i=53.0$ & $W i=w i / \sum w i$ & $\begin{array}{l}W Q \mid=222.6 \\
3\end{array}$ \\
\hline
\end{tabular}

Table 2: Mean Concentration of metals (mg/L) and Metal Pollution Index (MPI) of Groundwater samples.

Table 3: Relative Weight of Physiochemical Parameters and Water Quality Index (WQI) of Groundwater samples. 
Page 4 of 6

Table 2 shows that sampling site A has the highest MPI as such the worst water quality in terms of metal concentration while the sampling site $\mathrm{E}$ has the lowest MPI as such the best water quality.

Comparing results obtained from Table 2 and 3 it can be deduced that all the trace metals from the individual sites were within specification except chromium, nickel, cadmium and lead. Table 3 also indicates that the mean concentrations of the individual metallic ions from the five sampling sites were within specification except those highlighted [26].

Table 4 shows the WQI of water from the individual location. From Table 4 it can be deduced that water from locations A and B are classified as 'very poor water' this is not unconnected with the high concentration of trace metals especially $\mathrm{Cd}$ and $\mathrm{Pb}$ in these water samples.

\begin{tabular}{|l|l|l|}
\hline Sample & WQI & Water Classification Type \\
\hline A & 290 & Very Poor Water \\
\hline B & 260 & Very Poor Water \\
\hline C & 125 & Poor Water \\
\hline D & 315 & Water unsuitable for drinking \\
\hline E & 124 & Poor Water \\
\hline
\end{tabular}

Table 4: Water Quality Index Classification of Groundwater Samples from individual Sites.

The suitability of the groundwater in the study area for drinking and other purposes were determined by comparing the analytical results of the groundwater samples with the World Health Organization permissible limits [27]. The mean of physiochemical parameters and the metal concentration of the groundwater samples from the different locations are shown in Table 1 and 2 respectively. Table 1 shows that $\mathrm{pH}$ of the water samples from the five sampling locations ranges from 7.10 to 7.30. The $\mathrm{pH}$ of the groundwater samples from each of the location is within World Health Organization (WHO) permissible limit for good quality. Drinking water with an elevated $\mathrm{pH}$ above 11 can cause irritation of the eye, skin and mucous membrane whereas consuming water with $\mathrm{pH}$ below 4 can result in serious health defects due to the corrosive nature of the water [28].

The WHO permissible limit for alkalinity $<5.00 \mathrm{mg} / \mathrm{L}$ for potable water. The results from Table 1 shows that all groundwater samples from the five sampling locations were within specification [26].

The stipulated permissible limits by WHO for conductivity is $<1000$ $\mu \mathrm{S} / \mathrm{cm}$, TDS is $500 \mathrm{mg} / \mathrm{L}$, TSS of $500 \mathrm{mg} / \mathrm{L}$, sulphates and chlorides is $250 \mathrm{mg} / \mathrm{L}$ while nitrate of $45 \mathrm{mg} / \mathrm{L}$. Results from groundwater analysis as shown in Table 1 indicates groundwater samples from the five sampling locations were within WHO specification. Drinking water with high conductivity could lead to different forms diseases especially kidney disease [5].

Hardness of water is caused by the presence of $\mathrm{Ca}^{2+}$ and $\mathrm{Mg}^{2+}$. It is known that hard water is usually associated with heart disease and unsuitable for domestic use. Hardness of water is classified in degrees as soft 0 to $75 \mathrm{mg} / \mathrm{L}$; moderate 75 to $150 \mathrm{mg} / \mathrm{L}$; hard 150 to $300 \mathrm{mg} / \mathrm{L}$; very hard $>300 \mathrm{mg} / \mathrm{L}$ [28]. The groundwater study has hardness in the ranges of 3.00 to $5.00 \mathrm{mg} / \mathrm{L}$ indicating that they are soft water.

\section{Trace metals and metal pollution index (MPI)}

Metals which occurs at $1000 \mathrm{mg} \mathrm{kg}^{-1}$ or less in the Earth's crust are referred to as trace metals. They can be classified as light or heavy depending on their densities. Some may have high density $\left(>7 \mathrm{~g} / \mathrm{cm}^{3}\right)$ and atomic weight $(>20)$. Some trace metals, such as cadmium, mercury and lead, are remarkably hazardous while others like chromium, copper, iron, nickel and zinc are essential micronutrients which are important to plants and animals, but can be toxic in high concentration or certain forms [4-29]. Trace metals are major source of pollution not just because they are toxic above a relatively certain concentration but also because they are persistent, remaining in the environment long after the source of pollution has been removed [30]. Owing to their high toxicity, Cadmium, Chromium and Lead rank among metals with the highest priority as far as public health is concerned as such they are considered systemic toxicants known to induce multiple organ damage, even at lower levels of exposure [31]. They are also classified as human carcinogens according to the U.S. Environmental Protection Agency, and the International Agency for Research on Cancer [32]. The concentrations of $\mathrm{Ni}, \mathrm{Cd}$ and $\mathrm{Pb}$ were higher than stipulated limits of $0.02,0.003$ and $0.01 \mathrm{mg} / \mathrm{L}$ for safe drinkable water by WHO [27].

Results of the analysis of the trace metals concentrations for the groundwater samples were employed to calculate the MPI (Table 2). Water quality has been classified by some researchers using the MPI. Water with $\mathrm{MPI}<0.3$ are grouped in Class I and they are referred to as 'Very Pure', while those with MPI between 0.3 and 1.0 are in Class II and they are referred to as 'Pure. Those with MPI between 1.0 and 2.0 are grouped in Class III and they are termed as 'Slightly affected' while Class IV are termed 'Moderately affected' with an MPI between 2.0 and 4.0. Water samples with MPI between 4.0 and 6.0 are grouped in Class V and they are termed 'Strongly affected', while those with MPI $>6.0$ are seriously affected $[16,17]$. Deduction from the analysis of the MPI as shown in Table 2 shows that groundwater samples from the five sampling sites are between 0.33 and 0.46 (Class II), hence they are not very pure. The groundwater may require mild treatment in order to meet WHO standard for portability.

\section{Water quality index (WQI)}

A relative weight was assigned for each parameter based on their importance to water quality as shown in Table 3. An average of the parameters from each of the sampling location was obtained and the overall WQI of water from the 5 sampling locations was calculated as shown in Table 3 using equation 6. Water quality has also been classified based on WQI, water with WQI of $<50,50-100,100-200$, 200-300 and $>300$ are classified as excellent water, good water, poor water, very poor water and water unsuitable for drinking purposes respectively. The higher the WQI, the poorer the water quality [25-39]. The impact of the high concentration of trace metals such as $\mathrm{Cr}, \mathrm{Ni}$, $\mathrm{Cd}$, and $\mathrm{Pb}$ were evident in the WQI of the water samples from the individual sites. The sampling location $\mathrm{D}$ has the highest concentration of $\mathrm{Cd}$ and is classified as unsuitable for drinking, sampling locations $\mathrm{C}$ and $\mathrm{E}$ are all classified 'poor water' due to their WQI as shown in Table 4 .

\section{Conclusion}

The suitability of groundwater for both drinking and domestic purposes depends on major factors such as the physicochemical properties and trace metals concentration. The location as well as the 
depth of groundwater are basic factors that equally affect its quality. Water quality index (WQI) and metal pollution index (MPI) are key performance indicators that determines the quality of water and they are dependent on the physicochemical properties and trace metal level in water. Though most of the parameters of the water samples from the five locations under study were within acceptable standard by WHO, the WQI and MPI of the water samples confirmed the fact that water from the five locations need mild treatment before the groundwater can used for drinking purposes and this is not unconnected with the high concentration of toxic trace metals like cadmium, chromium, nickel and lead which were above WHO 2006 permissible limits for drinking water. Continuous monitoring of these trace metals is therefore advocated to prevent the concentration from reaching alarming level which can constitute possible public health implications on the users.

\section{Acknowledgements}

The authors are sincerely grateful to the entire staff of Jawura Environmental Services

27, St Andrews street, Rumubiakani, Port Harcourt for assistance in the analysis of the samples. We also appreciate Prof Leo. C. Osuji for immense contributions and advise that brought this work to fruition.

\section{References}

1. Jayaprakash M, Giridharan L, Venugopal S, Krishna KSP, Periyakal P (2008) Characterization and evaluation of the factors affecting the geochemistry of groundwater in Neyveli Tamil Nadu India. Environmental Geology 54: 855-867.

2. Ballukraya PN, Ravi R (1999) Characterization of groundwater in the unconfined aquifer of Chennai city India. Journal of the Geological Society of India 54: 1-11.

3. Milovanovic M (2007) Water quality assessment and determination of pollution sources along the Axios/Vardar River, Southeastern Europe. Desalination 213: 159-173.

4. Onojake MC, Frank O (2013) Assessment of heavy metals in a soil contaminatedby oil spill: a case study in Nigeria. Chemistry and Ecology 29: 246-254.

5. Chikwe TN, Onojake MC (2017) An appraisal of physicochemical parameters and some trace metals at the disposal points of five industrial effluents in Trans-Amadi Industrial Area of Port Harcourt, Nigeria. Journal of Applied Science and Environmental Management 20: 31-37.

6. Richter BC, Kreitler CW (1993) Geochemical Techniques for Identifying Sources of Ground-Water Salinization. CRC Press, p: 258.

7. Singh PK, Tiwari AK, Panigarhy BP, Mahato MK (2013a) Water quality indices used for water resources vulnerability assessment using GIS technique: a review. International Journal of Earth Science and Engineering 6:1594-1600.

8. Bordalo AA, Nilsumranchit W, Chalermwat K (2001) Water quality and uses of the Bangpakong River (Eastern Thailand). Water Research 35: 3635-3642.

9. Cude CG (2001) Oregon Water Quality Index: a tool for evaluating water quality management effectiveness. Journal of American Water Recourses Association 37: 125-137.

10. Kannel PR, Lee S, Lee YS, Kanel SR, Khan SP (2007) Application of water quality indices and dissolved oxygen as indicators for river water classification and urban impact assessment. Environmental Monitoring and Assessment 132: 93-110.

11. Mahato MK, Singh PK, Tiwari AK (2014) Evaluation of metals in mine water and assessment of heavy metal pollution index of East Bokaro Coalfield area, Jharkhand, India. International Journal of Earth Science and Engineering 7: 1611-1618.
12. Prasad B, Kumari P, Bano S, Kumari S (2014) Ground water quality evaluation near mining area and development of heavy metal pollution index. Applied Water Science 4: 11-17.

13. Logeshkumaran A, Magesh NS, Godson PS, Chandrasekar N (2014) Hydro-geochemistry and application of water quality index (WQI) for groundwater quality assessment, Anna Nagar, part of Chennai City, Tamil Nadu, India. Applied Water Science 5: 335-343.

14. Bhutiani R, Khanna DR, Kulkarni DB, Ruhela M (2014) Assessment of Ganga river ecosystem at Haridwar, Uttarakhand, India with reference to water quality indices. Applied Water Science 6: 107-113.

15. Panigrahy BP, Singh PK, Tiwari AK, Kumar B, Kumar A (2015) Assessment of heavy metal pollution index for groundwater around Jharia Coalfield region, India. Journal Biodiversity and Environmental Science 6: 33-39.

16. Lyulko I, Ambalova $\mathrm{T}$, Vasiljeva $\mathrm{T}$ (2001) Integrated water quality assessment in Latvia. MTM (Monitoring Tailor-Made) III, proceedings of international workshop on information for sustainable water management. The Netherlands, pp: 449-452.

17. Caerio S, Costa MH, Ramos TB, Fernandes F, Silveira N (2005) Assessing heavy metal contamination in Sado Estuary sediment: an index analysis approach. Ecological Indicators 5: 155-169.

18. Udom GJ, Amah EA (2006) Quality status of ground water in Yenagoa and its Environs. Bayelsa State, Nigeria. Journal of Scientific and Industrial Studies 4: 45-51.

19. Etu-Efeotor JO, Odigi MT (1983) Water supply problems in the Eastern Niger Delta. Bulletin Nigeria Mining Geosciences Association 20: 183-1992.

20. Etu-Efeotor JO, Akpokodje EG (1990) Aquifer systems of the Niger Delta. Journal of Mining and Geo-Engineering 26: 279-284.

21. Ngah SA, Nwankwoala HO (2013) Salinity dynamics: Trends and vulnerability of aquifers to contamination in the Niger Delta. Comprehensive Journal of Environment and Earth Sciences 2: 18-25.

22. American Standard for Testing and Materials (ASTM D5907) (2010) Standard test method for Silt Density Index for Filterable matter (Total dissolved solids) and Nonfilterable matter (Total suspended solids) in Water 11: 4-6.

23. Tamasi G, Cini R (2004) Heavy metals in drinking waters from mount Amiata. Possible risks from arsenic for public health in the province of Siena. Science of the Total Environment 327: 41-51.

24. Subba Rao N (1997) Studies of water quality index in hard rock terrain of Gurtur district, Andra Pradesh, India. National Seminar on Hydrology of Precambrian Terraina and hard water area pp: 129-134.

25. Vasanthavigar M, Srinivasamoorthy $\mathrm{K}$, Vijayaragavan K, Rajiv GR, Chidambaram S, et al. (2010) Application of water quality for groundwater quality assessment: Thirumanimuttar Sub basin, Tamil Nadu, India. Environmental Monitoring Assessment 171: 595-609.

26. World Health Organization (WHO) (2011) World Health Organization Guidelines for drinking water Edn. 4 th.

27. World Health Organizatio (WHO) (2006) Guidelines for drinking-water quality, 3rd edition: Volume 1 - Recommendations. World Health Organization, Geneva.

28. Sawyer GN, Macartly DL, Parkin GF (2003) Chemistry for environmental engineering and science. Edn. 5th McGraw Hill New York pp: 752.

29. Bonetti A, Leone R, Muggia F, Howell SB (2009) Platinum and other heavy metal compounds in cancer chemotherapy: Molecular mechanisms and clinical applications. Humana Press, New York.

30. Voutsinou-Taliadouri T (1981) Metals, Metalloids, and Radionuclides in the Baltic Sea ecosystem. Science Direct Elsevier 5: 40-55.

31. Goyer RA (2001) Toxic effects of metals. In: Klaassen CD, editor. Cassarett and Doull's Toxicology: The basic science of poisons. New York: McGraw-Hill Publisher: pp: 811-867.

32. Cincinnati OH (2009) United States Environmental Protection Agency (USEPA), Method 415.3: Determination of total organic carbon and specific UV Absorbance at $254 \mathrm{~nm}$ in Source Water and Drinking Water. 
Citation: Chikwe TN, Onojake MC (2018) Hydrochemical Characteristics and Potability Indices of Groundwater from Ogbia Local Government Area of Bayelsa State, Nigeria. J Environ Anal Chem 5: 244. doi:10.4172/2380-2391.1000244

Page 6 of 6

33. Adejuwon JO (2012) Rainfall seasonality in the Niger Delta Belt, Nigeria. Journal of Geography and Regional Planning 5: 51-60.

34. Asonye CC, Okolie NP, Okenwa EE, Iwuayanwu UG (2007) Some physico chemical characteristics and heavy metal profiles of Nigerian rivers, streams and waterways. African Journal of Biotechnology 6: 617-624.

35. Edmond JM, Palwer MR, Measures CF, Grant B, Stallard RF (1995) The fluvial geochemistry and denudation rate of the Guayana Shield in Venezuela. Geochim Coscochim Acta 59: 3301-3323.

36. Hem JD (1985) Study and interpretation of the chemical characterization of natural Water. United States Geological Survey water supply paper, Edn 3rd 1-263.
37. Pacyna JM (1996) Monitoring and assessment of metal contaminants in the air. Chang LW, Magos L, Suzuli T, editors. Toxicology of Metals. Boca Raton, FL: CRC Press; pp: 9-28.

38. Pang Z, Yuan L, Huang T, Kong Y, Liu J (2013) Impacts of human activities on the occurrence of groundwater nitrate in an alluvial plain a multiple isotopic traces approach. Journal of Earth Science 24: 111-124.

39. Sadiq M (1992) Toxic metal chemistry in marine environments. Marcel Dekker, New York, p: 390. 